\title{
Meningkatkan Kemampuan Reading Comprehension Siswa SMA Negeri 1 Kebomas Melalui Extensive Reading
}

\author{
Lilik Sri Wahyuningsih \\ SMA Negeri 1 Kebomas, Gresik Provinsi Jawa Timur \\ Corresponding Author. Email: lilikhosnaidi69@gmail.com
}

\begin{abstract}
This study aims to improve reading comprehension skills of SMA Negeri 1 Kebomas students through extensive reading. This research is a classroom action research conducted in three cycles by combining qualitative and quantitative methods. The sample of this research was students of class XI IPA 2 SMA Negeri I Kebomas. The research instrument used tests, observations, and questionnaires. The data analysis technique of this research is using descriptive analysis. The results of this study indicate that there is an increase in student reading comprehension learning outcomes as evidenced by an increase in test results during the study.
\end{abstract}

\begin{abstract}
Abstrak: Penelitian ini bertujuan untuk meningkatkan kemampuan reading comprehension siswa SMA Negeri 1 Kebomas melalui extensive reading. Penelitian ini merupakan penelitian tindakan kelas yang dilaksanakan dalam tiga siklus dengan menggabungkan antara metode kualtatif dan kuantitatif. Sampel penelitian ini adalah siswa kelas XI IPA 2 SMA Negeri I Kebomas. Instrumen penelitian ini menggunakan tes, observasi, dan angket. Teknik analisis data penelitian ini menggunakan analisis deskriptif. Hasil penelitian ini menunjukkan bahwa ada peningkatan hasil belajar reading comprehension siswa yang dibuktikan dengan peningkatan hasil tes selama penelitian.
\end{abstract}

Article History

Received: 02-12-2020

Revised: 03-01-2021

Published: 07-01-2021

\section{Key Words:}

Reading Comprehension, Extensive Reading.

\section{Sejarah Artikel}

Diterima: 02-12-2020

Direvisi: 03-01-2021

Diterbitkan: 07-01-2021

\section{Kata Kunci:}

Reading Comprehension, Extensive Reading.

How to Cite: Wahyuningsih, L. (2021). Meningkatkan Kemampuan Reading Comprehension Siswa SMA Negeri 1 Kebomas Melalui Extensive Reading. Jurnal Paedagogy, 8(1). doi:https://doi.org/10.33394/jp.v8i1.3325

\section{Pendahuluan}

Membaca merupakan kebutuhan yang sangat penting bagi para siswa, sehingga perlu adanya usaha-usaha untuk mengajak siswa mempunyai kebiasaan dan kesenangan dalam membaca. Khususnya dalam pelajaran bahasa Inggris, membaca sangat diperlukan karena pengajaran bahasa Inggris sekarang ini sangat berbeda dengan pengajaran sebelumnya. Pemahaman membaca merupakan salah satu keterampilan bahasa Inggris yang diajarkan di sekolah (Sumaryani, 2015; Permana et al., 2019). Bisa membaca dan memahami materi bahasa inggris dengan baik adalah tujuan utama belajar bahasa inggris (Muhtasim, 2020; Kamarudin, 2016 \& 2020).

Berdasarkan kurikulum 2004, Tujuan pengajaran bahasa Inggris bagi sekolah dasar atau dibawahnya adalah untuk memahami materi pemahaman jenis-jenis text dalam bahasa Inggris. (Depdiknas, 2003). Disamping pemahaman terhadap jenis-jenis text, siswa juga harus mampu menggunakan jenis-jenis text tersebut dalam kehidupan sehari-hari. Jadi saat ini siswa mempunyai beban yang lebih berat dalam belajar Bahasa Inggris. Siswa harus mempunyai perbendaharaan kata yang lebih banyak.

Untuk meningkatkan perbendaharaan kata, siswa harus mampu membaca dengan baik. Untuk mampu membaca dengan baik, siswa harus mempunyai kesenangan dan kemamuan membaca. Sadtono (1995) menyatakan bahwa kemampuan membaca bahasa Inggris para siswa kita sangat kurang, utamanya dalam reading comprehention. Berapa nilai kemampuan membaca siswa dapat dilihat dari rapor siswa, dimana dalam rapor nilai bahasa 
Inggris tersebut dirinci sesuai kemampuan yang harus dimiliki siswa yang diantaranya kemampuan mendengar, berbicara, membaca dan menulis. Jadi dari nilai rapor, kita bisa melihat bagaimana kemampuan membaca siswa. Karena membaca merupakan kunci dari segala kemampuan. Jika kemampuan membacanya bagus, siswa akan mampu melakukan kemampuan yang lain dengan bagus juga.

Kenyataan di lapangan, masih banyak siswa yang tidak suka membaca karena berbagai alasan sehingga mempengaruhi hasi belajar siswa. Salah satunya disebabkan karena kurangnya motivasi dan kemampuan untuk membaca, utamanya untuk pemahaman bacaan (reading comprehension). Selain itu penyebab yang lain adalah karena waktu yang disediakan juga sangat terbatas. Suasana kelas juga sangat membosankan, karena biasanya pembelajaran hanya dilakukan di dalam kelas dengan materi atau bahan yang sangat terbatas. Biasanya siswa hanya membaca buku pelajaran yang telah ditentukan. Hal ini dikarenakan para siswa hanya membeli buku tertentu yang diwajibkan oleh sekolah. Siswa mau mencari buku atau bahan bacaan lain jika hanya ada tugas dari guru. Hal ini yang membuat siswa tidak mampu membaca dengan baik karena kurangnya latihan.

Menyadari kenyataan diatas, dipandang penting untuk mencari solusi, agar siswa punya kemauan dan ketertarikan untuk membaca yaitu dengan cara mengajak siswa membaca bahan-bahan bacaan yang lebih banyak melalui Extensive Reading. Sebagaimana yang disampaikan oleh David Eskey dalam Day Bamford (1998) "reading ... must be developed, and can only be developed, by means of extensive and continual practice. People learn to read, and to read better, by reading." Selanjutnya Sadtono (1995) juga menyatakan bahwa: "... sekolah seharusnya menyediakan bahan-bahan bacaan yang lebih banyak bagi para siswa sehingga mereka mempunyai kesempatan sebanyak mungkin untuk membaca disampimg bahan-bahan pelajaran utama yang harus dibaca. Exstensive Reading harus ditingkan. Untuk mencapai tujuan kemampuan membaca, sangat tidak mungkin untuk dicapai apabila tidak ada keseimbangan antara intensive dan extensive reading".

Menurut Day and Bamford (1998) Extensive Reading adalah membaca dalam jumlah yang sangat banyak dalam bahasa asing. Sedangkan Hornby (1995) menyatakan bahwa 'extensive' means: (1) large in area, (2) large in amount or scale. Simanjuntak dalam Rohmawati (2016) menyatakan bahwa salah satu dari prinsip-prinsip pembelajaran adalah bahwa membaca perlu di praktekkan. Dari beberapa pendapat tersebut bisa disimpulkan bahwa belajar membaca sangat penting dan perlu beberapa latihan serta tehnik atau cara. Membaca memerlukan latihan yang secara nyata. Hal ini bisa dilakukan dengan cara Extensive Reading. Melalui Extensive Reading, siswa mempunyai banyak pilihan materi dan jenis bacaan yang diinginkannya. Mereka juga mempunyai waktu yang lebih banyak dibandingkan dengan intensive reading.

Dalam pembelajaran membaca, guru berharap bahwa para siswa akan mampu memahami bacaan dan mengevaluasinya dengan baik tanpa adanya gangguan ketidakmampuan siswa dalam penguasaan struktur dan perbendaharaan kata. Bahkan siswa diharapkan mampu membaca tanpa adanya bantuan dari guru (independent readers). Adapun tujuan penelitian ini adalah untuk meningkatkan kemampuan reading comprehension siswa SMA Negeri 1 Kebomas melalui extensive reading.

\section{Metode Penelitian}

Penelitian ini menggunakan metode penelitian tindakan kelas. Tujuannya untuk mengontrol variabel yang ada, dan efek yang dihasilkan oleh sistem atau proses yang direncanakan. Sampel penelitian ini adalah siswa kelas XI IPA 2 SMA Negeri I Kebomas. 
Selain itu ada 2 pengamat lain yang mengamati peneliti, sehingga penelitian ini akan lebih obyektif. Peneliti merupakan guru di sekolah ini, sehingga peneliti dan subyek mempunyai hubungan yang sangat dekat dan memudahkan penelitian. Untuk mendapatkan data penelitian ini digunakan instumen diantaranya adalah: Tes, digunakan untuk mengukur kemampuan siswa dalam reading comprehention. Sebelum melakukan tes, siswa diberitahu apa saja materi yang akan di diujikan. Yang kedua observasi, dilakukan untuk mengumpulkan data dengan menggunakan instrumen kegiatan dan penerapan kegiatan selama proses belajar mengajar. Yang terkhir kuesioner, yang digunakan untuk mendapatkan informasi tentang tanggapan siswa dalam proses belajar mengajar.

Tehnik yang digunakan dalam menganalisa data dalam penelitian ini adalah deskriptif. Penelitian ini menggambarkan kegiatan siswa dan guru dalam proses belajar mengajar untuk mengetahui bukan hanya penguasaan secara individu tetapi juga secara klasikal. Data akan dianalisa dalam 4 cara: Menganalisa Isi, dengan menganalisa hasil kuesioner yang terdiri dari input, penguasaan, dan saran yang dilakukan oleh pengamat. Dilanjutkan dengan menganalisa proses penilaian /realibilitas. Sedangkan, analisa dibagi menjadi 2 yaitu Analisa prosentase deskriptif dan analisa hasil belajar. Pada data kuantitatif yang diambil dari isi analisa data, dan digambarkan dengan teknik prosentase. Sedangkan Analisa hasil belajar digunakan untuk penguasaan prinsip pembelajaran, telah dinyatakan bahwa siswa bisa melanjutkan ke materi berikutnya jika $85 \%$ dari jumlah seluruh peserta didik dalam satu kelas mendapatkan nilai $65 \%$. Ketika penguasaan siswa belum mencapai $85 \%$, siswa yang mempunyai nilai kurang dari $65 \%$ harus diremidi.

\section{Hasil Penelitian dan Pembahasan}

Penerapan extensive reading dalam penelitian ini melibatkan 2 pengamat, yang berasal dari sesama guru dengan tujuan untuk membantu peneliti dalam menyelesaikan penelitian ini secara sempurna. Penelitian ini terdiri dari 4 siklus, Siklus pertama terdiri dari 2 pertemuan, diawali dengan reading aloud dan dilanjutkan dengan tes untuk pertemuan kedua dengan hasil rata rata 4,63. Dari hasil diskusi antara peneliti dan pengamat, ditemukan beberapa kelemahan dintaranya, guru tidak menjelaskan langkah langkah dalam menerapkan model extensive reading. Guru lebih banyak mendominasi proses pembelajaran, sedangkan siswa cenderung pasif. Guru tidak menjelaskan apa yang seharusnya dilakukan siswa dalam proses pembelajaran extensive reading. Guru tidak memberikan motivasi terhadap siswa dalam menggunakan bahan bahan bacaan untuk extensive reading. Dari kelemahan kelemahan tersebut, untuk siklus berikutnya peneliti berusaha memperbaiki kekurangan yang ada pada siklus pertama.

Pada siklus kedua, perubahan mulai nampak tetapi kenaikan rata rata kelas masih belum memuaskan karena masih menggunakan metode read aloud. Hampir sama dengan siklus pertama, pertemuan pertama digunakan untuk penjelasan seklaigus penerapan extensive reading. Peneliti mulai mengatur proses pembelajaran dengan lebih baik, menjelaskan kata kata yang belumdimengerti oleh siswa dan mulai memberikan motivasi terhadap siswa tentang perlunya rasa percaya diri dalam membaca dan pentingnya reading comprehension. Rata rata yang dicapai pada siklus kedua adalah 5.73. Masih banyak siswa yang tidak memperhatikan penjelasan guru.

Berdasarkan pengalaman dari siklus 1 dan 2, peneliti mengubah strategi dengan menerapkan silent reading. Peneliti menjelaskan kepada para siswa bahwa membaca adalah sebuah proses, bisa dilakukan di dalam maupun di luar kelas, tanpa harus membaca dengan suara keras. Pada siklus ketiga, siswa terlihat lebih aktif dari pada guru. Siswa bisa mengatur 
waktunya dengan lebih baik, siswa bisa bekerja sama dengan temannya secara lebih baik. Guru lebih banyak memberikan motivasi terhadap siswa untuk menjawab pertanyaan dengan benar, membuat rangkuman dan memotivasi siswa untuk memiliki rasa percaya diri yang baik. Rata rata nilai siswa sudah mulai naik yaitu 6,37.

Pada siklus ke empat peneliti mulai mengatur segala persiapan dengan lebih baik, pada pertemuan pertama, dimulai dengan membagi kelompok, masing masing kelompok terdiri dari 2 siswa dilanjutkan dengan memberikan motivasi kepada siswa tentang pentingnya pemahaman bacaan atau reading comprehension. Peneliti menanyakan text atau bacaan yang belum dipahami oleh siswa, serta menjelaskan kata kata yang tidak dimengerti oleh siswa. Sebagian besar siswa terlihat lebih antusian dan lebih aktif. Pertemuan kedua dilanjutkan dengan tes. Proses pembelajaran pada pertemuan keempat terlihat lebih terarah dan lebih baik, peneliti bisa menjadi motivator dan fasilitator yang lebih baik. Rata rata yang dicapai siswa 6,98.

Berdasarkan pengamatan dari aktivitas siswa dan guru dalam proses pembelajaran di siklus awal, hasil yang didapatkan sangat rendah sehingga perlu untuk ditingkatkan. Dalam hal ini, peneliti memfokuskan diri dalam extensive reading dengan menggunakan reading aloud atau membaca secara keras dengan harapan siswa bisa menghasilkan kemmapuan membaca atau reading comprehension secara sempurna. Peneliti menemukan banyak kelemahan dengan dibuktikan dari hasil rata rata nilai yaitu 6,37. Berdasarkan hasil tersebut, Peneliti memutuskan untuk menggunakan silent reading atau membaca dalam hati. Berdasarkan analisa hasil, diproleh rata rata dari siklus ke 1 adalah 4,63, silus 2 mendapatkan rata rata 5,73, siklus ke 3 memeproleh angka 6,37 sedangkan siklus terakhi atau yang ke 4 hasilnya adalah 6,98. Ini menunjukkan adanya peningkatan dari siklus awal samapi siklus yang terakhir. Dapat dikatakan bahwa model extensive reading berhasil meningkatkan hasil belajar siswa, juga bisa dikatakan bahwa motivasi dan kemauan siswa dalam membaca menjadi lebih baik. Siswa menjadi lebih antusias dalam mengikuti proses pembelajaran. Extensive Reading mampu membuat siswa lebih tertarik dalam membaca, sehingga disarankan, bagi para guru untuk menggunakan model extensive reading untuk mendapatkan reading comprehension yang bagus, sehingga perlu disediakan buku-buku bacaan di dalam kelas. Penerapan extensive reading harus disertai dengan bahan bahan bacaan yang sesuai dengan kemampuan siswa.

\section{Kesimpulan}

Kesimpuan yang diperoleh dari hasil penelitian ini adalah extensive reading telah berhasil meningkatkan hasil belajar siswa yakni kemampuan reading comprehension. Selain itu juga motivasi dan kemauan siswa dalam membaca menjadi lebih baik. Siswa menjadi lebih antusias dalam mengikuti proses pembelajaran. Melalui extensive reading telah mampu membuat siswa lebih tertarik dalam membaca.

\section{Saran}

Berdasarkan hasil penelitian ini dapat disampaikan saran bahwa bagi para guru bahasa inggris agar dapat menggunakan model extensive reading untuk meningkatkan kemampuan reading comprehension siswa yang lebih baik, sehingga perlu disediakan buku-buku bacaan di dalam kelas. Penerapan extensive reading harus disertai dengan bahan bahan bacaan yang sesuai dengan kemampuan siswa. 


\section{Daftar Pustaka}

Arikunto, Suharsimi. (2008). Prosedur Penelitian : Suatu Pendekatan Praktek. Jogjakarta: Rineka Cipta

Brown, H. Douglas. (2000). Principles of Language Learning and Teaching. Englewood Cliff: Prentice Hall, Inc.

Day, Richard R. and Bamford, Julian. (1998). Extensive Reading In the Second Language Classroom. Cambridge: Cambridge University Press.

Depdiknas. (2003). Kurikulum 2004: Pedoman Khusus Pengembangan Silabus Berbasis Kompetensi Mata Pembelajaran Bahasa Inggris SMP. Jakarta: Depdiknas Dirjen PDMDPLT.

Kamarudin, K., \& Sugianto, N. (2020). A Readability Level of Reading Materials for Vocational High School Students in Lombok, NTB. Jurnal Paedagogy, 7(4), 265274. doi:https://doi.org/10.33394/jp.v7i4.2852

Kamarudin, K. (2016). The Use of Small Group Discussion in Teaching Reading Comprehension at SMAN 2 Mataram. Jurnal Kependidikan: Jurnal Hasil Penelitian dan Kajian Kepustakaan di Bidang Pendidikan, Pengajaran dan Pembelajaran, 2(2). doi:https://doi.org/10.33394/jk.v2i2.454

Muhtasim, M. (2020). UPAYA PENERAPAN METODE COOPERATIVE LEARNING TIPE GROUP INVESTIGATION UNTUK MENINGKATKAN HASIL BELAJAR DAN KETERAMPILAN MEMBACA BAHASA INGGRIS SISWA. Jurnal Paedagogy, 2(2), 59-69. doi:https://doi.org/10.33394/jp.v2i2.3049

Permana, D., Suadiyatno, T., \& Harmawati, S. (2019). Note-Taking Pairs Strategy Towards Students' Critical Thinking Ability In Reading Comprehension. Jurnal Kependidikan: Jurnal Hasil Penelitian dan Kajian Kepustakaan di Bidang Pendidikan, Pengajaran dan Pembelajaran, 5(2), 75-83. doi:https://doi.org/10.33394/jk.v5i2.1797

Rohmawati, D. L. (2016). Improving Students' Reading Comprehension Through Paired Storytelling in SMP N 1 Mojogedang. Seminar Nasional Kajian Bahasa, Sastra, dan Pengajarannya (SEMNAS KBSP) IV 2016.

Sadtono E. (1995). Perspektif Pengajaran Bahasa Inggris di Indonesia. Malang: IKIP Malang.

Sumaryani, L. (2015). Teaching Reading Strategies for Students at FPBS IKIP Mataram. Jurnal Kependidikan: Jurnal Hasil Penelitian dan Kajian Kepustakaan di Bidang Pendidikan, Pengajaran dan Pembelajaran, 1(2). doi:https://doi.org/10.33394/jk.v1i2.419 